\title{
Determinants Of Capital Structure Of Leasing Companies In Pakistan
}

\author{
Shazila Andaleeb \\ Department of Management Sciences, MAJU, Karachi \\ Muneer Ahmed Abbasi \\ Department of Business Administration, BBSUL, Karachi \\ Syed Iqbal Hussain Naqvi \\ Department of Commerce, FUUAST, A.H. Campus, Karachi \\ Shahan Ali \\ Department of Commerce, BBSUL, Karachi
}

\begin{abstract}
The purpose of the research is to study the determinants of capital structure of leasing companies in Pakistan listed on Karachi Stock Exchange during the period of 20062015. In this study data was collected from at Karachi Stock Exchange .In this study experts and professional can break down whether the practices in the exact corporate world are identified with the hypothetical perspectives of capital structure. This part of research provide us a review of the theoretical framework literature on capital structure whether the significance of leverage benefits and its cost will run the managers to make decisions based on leverage of capital structure and its market opportunities for guiding them to various debts and equity issues? Do managers have leverage targets change over the time or they adjust equity debt ratio continuously or they don't have targeted leverage to maintain? The unit of investigation is the recorded firms in PSX record with the negligible specialists' impedance. Study defines adjusted panel information which was gathered from secondary sources. The study applies econometrics displaying utilizing both single condition and diminishes condition models for panel information. Panel econometric procedures specifically pooled common minimum squares, settled impacts, and irregular impacts were utilized to research the effect of capital structure on execution of finance related firms recorded on the Karachi Stock Exchange from 2006-2015.
\end{abstract}

Keywords: Capital Structure, Leasing, Leverage

\section{Background of Study}

\section{INTRODUCTION}

This examination gives the significant data about the capital structure choice effects and firms qualities inspected to expand the determinants of capital structure rehearses. This is a pioneer research work towards the finding of capital structure determinants of leasing organizations in Pakistan by Titman and Wessels (1988). The creators give the significant proofs about the company's size, benefit, hazard, charges, development, substantial quality, capital ampleness, speculation, money streams and profit association with capital structure basic leadership criteria which can come about into unfavorable or positive connection between firm size and capital structure.

Year by year determination elements of capital structure choice stay tricky regardless of being included in endless hypothetical matters like pecking request hypothesis, exchange off hypothesis, flagging hypothesis (Frank and Goyal, 2003; Fama and French, 2005; Byoun, 2008; 
Roshan, 2009) looking at the different parts of capital structure basic leadership. There are scientists who takes after Modigliani and Miller (1958) and they utilizes diverse kind of hypotheses like clarifying the contentions for deciding the capital structure assortment in setting distinctive areas yet then again analysts (Hirshleifer, 1966; Stiglitz, 1969) are contending that the capital structure is unessential generally due to its effects available estimation of the firm. Different analysts available is of the supposition (Myers and Majluf, 1984; Graham, 2003) that contending the money related basic leadership is an endeavor towards the directors for offsetting their duty shields of higher obligations against the cost increase budgetary trouble.

Still, there is scarcely ever plain privilege on the determinants of capital structure and analysts are appeased in testing of getting a superior master on possessions cluster choices to add to the important writing.

\section{Overview of Leasing Companies of Pakistan}

At present there are 50 (monetary) leasing organizations in Pakistan. Leasing organizations are giving multi leasing administrations in Pakistan for various classifications of business. Property and cars (vehicles) are primary business classifications in Pakistan for renting. Auto leasing and house leasing organizations are giving their consultancy administrations in Pakistan for the sake of settled add up to general society or individual and organizations. A lease or occupancy is an agreement that exchanges the privilege to have particular property. In law, there are two sorts of property: verifiably, land is the more essential in light of the fact that, under ordinary circumstances, it holds the most elevated quality in monetarily created social orders.

Advancement of Leasing in Pakistan: The development of leasing in Pakistan especially in the formal segment goes back to June 1980 while, as indicated by a Report of the Council of Islamic Ideology, the idea of leasing was perceived as one of the money related administrations under the Islamic budgetary framework, which was later presented in the nation in 1985.

\section{Problem Statement and Objectives}

Problem Statement: Capital structure blend is a critical choice for any firm. Firms endeavor to pick suitable blend of obligation and value to bring their expense of capital at the least level. Budgetary directors dependably try endeavors to raise the abundance of shareholders since it is their center obligation. Significance of capital structure choice can't be overlooked. Suitable basic leadership with respect to financing blend can help firms to bring down their expense of capital which at last expands the estimation of firm. Capital structure choice is affected by numerous elements. It is essential to take watchful thought of those variables decently well be detailed. This study centers to porch out the particular elements of capital structure and their impact on financing blend particularly on renting and leasing industry.

\section{Objectives}

This concentrate for the most part centers to porch out firms' particular elements of capital structure choices for the recorded firms of renting industry. Aside from that, this concentrate additionally endeavors to discover:

- Effect of Profitability on capital structure choices,

- Effect of substantial quality of benefit after choosing capital structure,

- Influence of size on capital structure choices,

- Impact of development on capital structure choices,

- Influence of business and monetary danger on capital structure choices,

- Effect of on capital structure choices, and 
- Impact of assessment shield on capital structure decisions.

\section{Justifications and Implications}

This study is done to clarify the effect of capital structure in the money related execution of the recorded firms on Karachi Stock Exchange trade. In this study experts and professional can break down whether the practices in the exact corporate world are identified with the hypothetical perspectives of capital structure or not. This study is likewise a commitment of information in the field of corporate account which would give new thoughts to specialists and researchers.

\section{Assumptions and Limitations}

We intend to test a basically entrenched hypothesis of capital structure determinants on the generally untested Swedish business sector, while including two extra segments: The expense of capital and the administration division, as opposed to the regularly examined fabricating/delivering segment, which is additionally incorporated into the study.

This study:

- Examines capital structure drivers proposed by the exchange off hypothesis and pecking request hypothesis to decide the pertinence of these speculations for Pakistani firms.

- Differentiates between industry sort and between eras, to figure out if the hypotheses can be reasonably reached out to various sorts of firms and how the significance of drivers changes in various eras.

- Analyzes the informative force of capital structure, considered in the main segment of the paper, over the expense of capital.

The exact exploration covers bookkeeping and business sector information just from organizations recorded on the Karachi Stock Exchange and is constrained to the period 20062015. Organizations included are limited to a more extensive meaning of assembling/creating industry and administration industry. Money related organizations are prohibited from the specimen, since they are described by high influence proportions and a double part as both moneylenders and borrowers. Further, organizations that depend on bond-advance financing were expelled from the example, since the structure of those advances and the installment streams are obscure, or if nothing else amazingly hard to assemble in a complete and solid way. The postulation is additionally obliged to organizations that stay dynamic all through the whole study time frame, suggesting that organizations that went bankrupt or were inert amid this period were excluded.

\section{Theories of Capital Structure}

\section{LITERATURE REVIEW}

Capital structure is being determined through the maximization of the firm's value, this is introduced by Modigliani and Millers (1958). This part of research provides us a review of theoretical framework literature on capital structure whether the significance of leverage benefits, its cost will run the managers to make decisions based on leverage of capital structure and its market opportunities for guiding them to various debts and equity issues? Do managers have leverage targets change over the time or they adjust equity debt ratio continuously or they don't have targeted leverage to maintain? The answer to above query is that there are three basic theories of capital structure model available to support the solution towards these questions that are trade-off theory, pecking order theory and signaling theory because there is no other than that formula for capital structure exact maximization of firm's value. Researcher 
conducted a lot of empirical evidence from all over the world for testing the hypothesis on these given theories (Ross, et al 2008).

Principle underlying the theoretical capital structure discusses the lending and financing choices of the firms in terms of its static trade-off choice and pecking order framework choice that cover the several aspects like trade-off theory encompasses the exposure of firm's bankruptcy and its agency cost that effects directly towards the valuation in terms of taxes associated with debts uses. One of the cost is representing the bankruptcy cost in terms of liquidation cost that is valued in the liquidation of net assets of the firm. The higher cost will be incurred by the firm in terms of its financial cost due to potential liquidation costs (Cassar and Holmes, 2003).

\section{Trade-off Theory}

For capital structure trade-off theory is being very crucial in explaining the motive of the way towards the firms typical financing partly with debts and its equity. Trade-off theory states that financing benefits in terms of its debts that is tax shield advantage, agency benefit and also the cost of funding in terms of debts for example financial distress and its agency cost that is focusing on the maximization of valuation of the firm in terms of its offsetting cost benefits of debts and equity for making decision of financing the business.

\section{Pecking Order Theory}

The attention considerably goes towards the finance research scholars who practices the pecking order theory because it is being considered as a one of the most important and convincing theory of capital structure practice. According to Myers (1984) the pecking order theory was firstly introduced as an empirical test of pecking order followed by many scholars like Shyam, Sunder and Myers (1999), Myers and Majluf (1984). Argue that empirical test of pecking order is used by modified regression model based on empirical developed analysis methodology reporting about the firm follow up of a set pattern preferences using the internal generated and external options of funding by Shyam-Sunder.

\section{Signaling Theory}

Those indicating principle (ST) approach, initially created Toward ross. (1977), demonstrates that debt may be viewed as an approach with highlight investors' trust for. Those company; that is, In an organization issues the debt it gives a indicator of the. Businesses that the firm will be expecting sure trade streams in the future, Likewise the. Vital What's more investment installments once debt need aid an altered contractual commitment. Which a firm need on pay out about its money streams. Accordingly the larger amount from claiming obligation. Indicates the manager's certainty done future money streams.

\section{Profitability}

The important determinant of capital structure is profitability of the firm that affects the decision making related to the capital structure of the firm. According to the pecking order theory the firms gives preference to use retained earnings firstly as an investment of funds that are necessary. The higher the profitability of the firm the lesser is the leverage. Two major alternatives are being measured for the profitability of the firm that is Return On Asset(ROA) and Return On Equity(ROE) from which both of the basic earnings after taxes is calculated. Leverage and profitability of the firm is negatively related with each other because finance managers use to prefer more profits instead of leverage to financial investment (Al-Fayoumi and Abuzayed, 2009; Gropp and Heider, 2009). 


\section{Risk}

Business risk is considered to be the one of the key important factor for capital structure practices of the firm. Bhaduri (2002) states that commitment of debts involves periodic payment commitment therefore high leverage of the firm prone to the distress cost of finance and volatile income of the firm are more likely to have less leverage (Bhaduri, 2002, p. 202). Bankruptcy theory defines that there is a negative relationship in between the capital structure and business risk. The institutional investment trend of the firm towards the low business risk because the firm with its high volume of volatility of their returns tend to be highly profitable to default and to become bankrupt. Therefore it tends to be negative in relation with the business risk as compare to the institutional ownership of the firm. The recent research study defines that the use of standard deviation of Return On Assets is the main indicator for the business risk of the firm.

\section{Taxes}

It is being considered that taxes are the foremost important factor to be believe for the determining of capital structure and its decision. Firms with high payment of taxes have more leverage to obtain its tax shield gain. (Auerbach, 1985). Tax is measured as a payment of tax usage decision and computed as by tax rate multiply by its earnings before taxes for avoiding the potential problems of taxation deferred. There is a positive relationship in between the tax and leverage of the leasing companies of Pakistan.

\section{Growth}

In different type of non financial studies it is defined that (Barclay et al., 1995; Shah and Khan, 2007), argues about the growth opportunities are negatively related with the leverage of the firm because it tend to hold the more real options for future investment as in comparison with its low growth opportunities (Myers, 1977). For instance the firms such as leasing firm have higher number of deposits, whereas leasing companies do have higher number of policies from which we expect the positive relationship in between growth opportunities and firms leverage because leasing companies borrows huge amount of money from different banks for increasing their lease agreements. The percentage is calculated through the change in total assets from prior year (see, e.g. Ramlall, 2009). Hovakimian et al. (2004) argues that the high growth opportunities of the firm that bringing more capital gains towards the institutional investor will lower down the ones growth. Therefore growth opportunity is being considered as a positive signal for institutional investors and study uses the market-to-book approach as an indicator towards the growth opportunity of the firm.

\section{Size}

Size of the firm is one of is one of the important determinant of capital structure of the firm and its different sizes that have different types of characteristics. For example small firms tend to have more problems as compared to large firms because they have less asymmetric information problems to share and they specifically share more information in the case of outside investors (Rajan and Zingales, 1995). Expected relationship in between the size and leverage is positive because it argues the leverage increases the value of the firm as the firm increases(Noe, 1988; Harris and Raviv, 1990). Firm size play an important role as large firms are less prone to bankruptcy and are more diversified, therefore a positive relationship is expected (Titman andWessels, 1988; Bhaduri, 2002). Resources are required by large firms and the ability to the maximization of the risk is also required for their stock investment that is why it is less financial distressed and bankruptcy risk is also low risk (O'Brien and Bhushan, 1990; Tong and Ning, 2004). Logarithm natural to total assets is used as a proxy for the size of the firm. 


\section{Asset Structure}

Asset structure is one of the crucial determinants for the new firm capital structure up to the extent that the tangible assets and generics resulted into the firms that are having more liquidation value (Harris and Raviv, 1991; Titman and Wessels, 1988). Many research studies revealed that the leverage is positively related with the firm's assets. According to Myers (1977) the consistent argument over the tangibility of the asset such as fixed assets strengthen the higher debts level with comparison to intangible assets likewise as a growth opportunies. Assets could be redeployed in near future. Their inalienable values in view they are less specific particular ( Williamson , 1988; harris , 1994). Thus potentially reduces the cost of agency associated with debt usage connected with obligation use (Smith Also Warner , 1979; Stulz What's more johnson , 1985). Feri and. Jones (1979), bog (1982), in length and Matlitz (1985) Furthermore allen (1995) provide experimental. Proof of a certain relationship between debt Furthermore settled possessions. The experimental. Confirmation recommends a certain connection reliable with the hypothetical contentions. The middle of benefit structure Also power to vast organizations (Van der Wijst Furthermore Thurik , 1993;. Chittenden et al. , 1996; Michaelas et al. , 1999).

\section{Investment}

In the event that of financial institutions, those speculations would really significant over deciding the capital structure. Choices resulted that speculations hold numerous noteworthy. Part of the financial institution's possessions. Renting. Organizations dependably bring a huge sum for Venture. Previously, terms of the lease particular fund and for some situations venture. For lease account gets more than half of aggregate advantages. Moreover, investment to terms of the lease fund will catch. How those leasing organizations account their lease agreements.

\section{Cash Flows}

cash flow appears to contrast crosswise over firms in the greatness of its effect on venture. Specifically, it seems to assume a more critical part for extensive firms than for little firms. While this might astonish at first sight, there are a few reasons why this impact may be watched. For instance, it might mirror the way that substantial firms have a tendency to have a lower relative income. Also, it might mirror the likelihood that extensive firms have a more different proprietorship structure, which tends to expand organization costs. Given size, the impact of income has a tendency to be bigger for firms in developing areas, in opposition to what one would expect subsequent to collateralizable total assets is liable to be bigger for this situation and the danger of lower. In any case, firms in developing segments need to back a higher rate of speculation. At last, when firms are ordered by, it gives the idea that income matters to some degree more for more current firms, as would be normal since data asymmetries are liable to be bigger for such firms and they have to back a higher speculation rate. Our outcomes propose that capital business sector defects ought to be an important element of any expansion to or reformulation of the change cost model of venture. In any case, the blended execution of $Q$ recommends that such expansions ought to be sought after in future work.

\section{Research Design}

\section{RESEARCH METHODOLOGY}

The unit of investigation is the recorded firms in PSX record with the negligible specialists' impedance. Study defines adjusted panel information which was gathered from secondary sources.

The study applies econometrics displaying utilizing both single condition and diminishes condition models for panel information. Panel econometric procedures specifically pooled 
common minimum squares, settled impacts, and irregular impacts were utilized to research the effect of capital structure on execution of finance related firms recorded on the Karachi Stock Exchange from 2006-2015.

Diverse restrictive hypotheses of capital structure are surveyed (the exchange off hypothesis, pecking request hypothesis, organization hypothesis, and hypothesis of free income) keeping in mind the end goal to define testable recommendations concerning the determinants of capital structure of the assembling firms. The examination is performed utilizing board information strategies for an example of 10 firms recorded on the Karachi Stock Exchange from 2006-2015.

Theoretically the study looks at firm level components that decide the capital structure of leasing companies in Pakistan. Right now, ten leasing companies are working in Pakistan; and the specialist trust that, for important examination, there is no compelling reason to test from the ten leasing companies as they are as of now few in number to gather data over the time of 2006-2015.

\section{Theoretical Framework and Hypotheses}

As showed by Miller, the estimation of the firm depends on upon the relative stature of each obligation rate, differentiated and the other two. As pros continued forward examining further the considered capital structure, a couple theories emerged, all of which completion up on the nearness of a perfect capital structure checking conforming the favorable circumstances and costs of commitment financing. The standard preferred standpoint of commitment financing is the way that interest portions are deducted in figuring assessable pay, allowing an "evaluation shield" for the associations. This "cost shield" licenses firms to pay lower charges than they should, while using commitment capital rather than using only their own capital. The costs of commitment can be seen generally from two unmistakable points of view. To begin with, there is an extended probability that a firm will be not capable successfully dealing with its commitment responsibilities (i.e. interest portions); thusly, there is an extended probability of indebtedness. Second, there are office costs of the credit pro's watching and controlling the affiliation's exercises. There are additional costs concerning the possibility of capital structure of the firm that rise up out of the way that directors have more information about the affiliation's future prospects than do examiners.

Figure 1

\section{Theoretical Model}

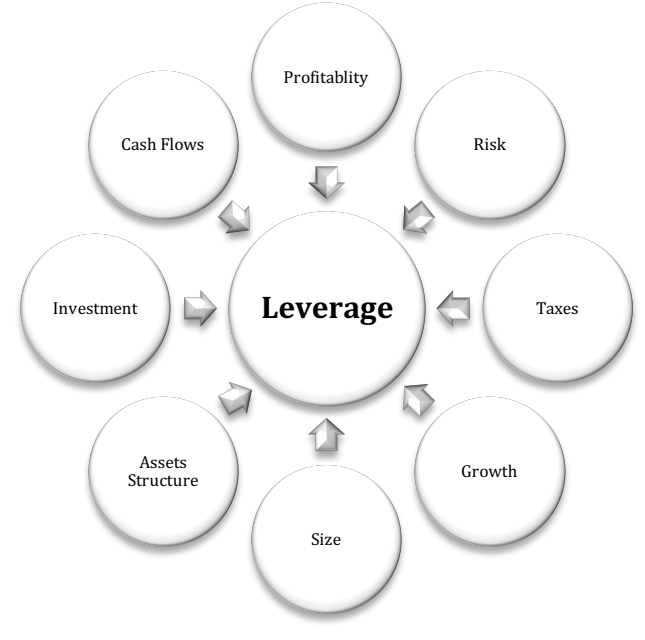


This study researches the determinants of capital structure of leasing firms in Pakistan for the period 2006 to 2015. Utilizing an adjusted board test, we find that size has a positive relationship, while benefit, liquidity and duty have a negative association with influence of the example firms. We likewise incorporate expansion and unmistakable resources for examine their association with the influence alongside alternate determinants of capital structure. If there should be an occurrence of higher swelling, for occasion, firms want to get more cash as opposed to issuing value. As a outcome, we expect a positive relationship amongst swelling and influence. By and large, substantial resources constitute a moderately little extent of aggregate resources if there should arise an occurrence of leasing organizations in Pakistan. In the lion's share of the cases, substantial resources are under $5 \%$ of the aggregate resources of any lease organization in Pakistan.

Table 2: Independent Variables \&Expected Signs

\begin{tabular}{|c|c|c|c|c|}
\hline & Variable Name & $\begin{array}{l}\text { Expected } \\
\text { Sign }\end{array}$ & $\begin{array}{l}\text { Reference from } \\
\text { Literature }\end{array}$ & $\begin{array}{l}\text { Theory } \\
\text { Support }\end{array}$ \\
\hline i. & Profitability & - & $\begin{array}{l}\text { Myers and Majluf (1984); } \\
\text { Titman and Wessels } \\
\text { (1988); Abor (2005) }\end{array}$ & Packing Order \\
\hline ii. & Risk & - & Ooi (1999); Amidu (2007) & $\begin{array}{c}\text { Packing Order } \\
\text { Trade-off }\end{array}$ \\
\hline iii. & Taxes & + & $\begin{array}{c}\text { Ooi (1999); DeAngelo and } \\
\text { Masulis (1980) }\end{array}$ & Trade-off \\
\hline iv. & Growth & - & Ooi (1999) & Trade-off \\
\hline v. & Size & + & $\begin{array}{l}\text { Titman and Wessels } \\
\text { (1988); Ooi (1999) }\end{array}$ & $\begin{array}{c}\text { Packing Order } \\
\text { Trade-off }\end{array}$ \\
\hline vi. & Assets Structure & + & $\begin{array}{l}\text { Rajan and Zingales } \\
\text { (1995); Rahman and } \\
\text { Kakakhel (2016) }\end{array}$ & Trade-off \\
\hline vii. & Cash Flows & + & Shoney and Koch (1996) & $\begin{array}{c}\text { Signaling } \\
\text { Packing Order }\end{array}$ \\
\hline
\end{tabular}

The following hypotheses derived from the literatures will be ultimately defined as under:

H1: Profitability significantly impacts capital structure

H2: Risk significantly impacts capital structure

H3: Taxes significantly impacts capital structure

H4: Growth significantly impacts capital structure

H5: Size of the company significantly impacts capital structure

H6: Asset structure significantly impacts capital structure

H7: Cash flows significantly impacts capital structure

\section{Data and Description}

Information accumulation is the way toward social occasion and measuring data on variables of enthusiasm, in a set up methodical design that empowers one of the major one to answer examination questions that is expressed, test theories, and assess results. The information accumulation segment of examination is regular to all fields of study including physical and sociologies, humanities, business, and so forth. While strategies shift by order, the accentuation on guaranteeing precise and fair gathering continues as before. 


\section{Empirical Model}

Along these lines, we additionally apply the Hausman (1978) test keeping in mind the end goal to choose between the settled and arbitrary impact estimators (see, e.g. Bevan also, Danbolt, 2004; Voutsinas and Werner, 2011). The invalid speculation is that there is critical connection between's the surreptitiously firm-particular arbitrary impacts and the regressors. On the off chance that there is no such relationship, then the irregular impacts model may be all the more effective and tightfisted. On the other hand, the arbitrary impacts model would be conflictingly assessed and the settled impacts model would be the model of decision. In all cases, the pvalues for the Hausman test demonstrate that the irregular impacts model is the favored determination.

Table 3: Variables and Details

\begin{tabular}{|c|c|c|c|}
\hline S. No. & Variable Name & Proxy & Symbol \\
\hline 1. & Leverage & Total Debt to Total Assets & TD/TA \\
\hline 2. & Leverage & Total Debt to Total Equity & TD/TE \\
\hline 3. & Profitability & Return on Assets & ROA \\
\hline 4. & Risk & Standard Deviation of Daily Returns & SD.R \\
\hline 5. & Taxes & Pre-tax Profit to After-tax Profit & PTP/ATP \\
\hline 6. & Growth & Percentage Change in Turnover & PCT \\
\hline 7. & Size & Log of Total Assets & LTA \\
\hline 8. & Assets Structure & Fixed Assets to Total Assets & FA/TA \\
\hline 9. & Investments & Investments to Total Assets & INV/TA \\
\hline 10. & Cash Flows & Operating Cash Flows to Total Assets & OCF/TA \\
\hline
\end{tabular}

An assortment of meanings of influence have been utilized as a part of the writing, mostly either concentrating on book or market esteem estimations. In any case, the decision of the definition is to a great extent driven by the exploration inquiries being raised and in addition the accessibility of proper information. The reliant variable, influence in the present study is measured in three ways:

(1) complete obligation to aggregate resources (see, e.g. Bevan and Danbolt, 2000; Antoniou et al., 2008; Huang and Song, 2002; Chen, 2004);

(2) long haul obligation to aggregate resources (see, e.g. Bevan and Danbolt, 2000; Huang and Song, 2002; Buferna et al., 2005); and

(3) transient obligation to all out resources (see, e.g. Kakani and Reddy, 1998; Ramlall, 2009).

The equation (1) is regressed through fixed effect panel least square method.

$$
\begin{aligned}
\mathrm{TD} / \mathrm{TA}_{\mathrm{i}, \mathrm{t}} & =\beta_{0}+\beta_{1} \mathrm{ROA}_{\mathrm{i}, \mathrm{t}}+\beta_{2} \mathrm{SD} . \mathrm{R}_{\mathrm{i}, \mathrm{t}}+\beta_{3} \mathrm{PTP} / \mathrm{ATP}_{\mathrm{i}, \mathrm{t}}+\beta_{4} \mathrm{PCT}_{\mathrm{i}, \mathrm{t}}+\beta_{5} \mathrm{LTA}_{\mathrm{i}, \mathrm{t}}+ \\
\beta_{6} \mathrm{FA}_{\mathrm{T}} \mathrm{TA} &
\end{aligned}
$$

Then, the parameter $\beta_{0}$ is an intercept dummy variable that captures the effect of total assets over total debts on starting salary, all else held constant.We now turn to estimation of a asset equation using data from the Panel Study for the years 2006-2015.

The equation (2) is regressed through Random Effect Generalized least square method. 
$\mathrm{TD} / \mathrm{TE}_{\mathrm{i}, \mathrm{t}}=\beta_{0}+\beta_{1} \mathrm{ROA}_{\mathrm{i}, \mathrm{t}}+\beta_{2} \mathrm{SD} . \mathrm{R}_{\mathrm{i}, \mathrm{t}}+\beta_{3} \mathrm{PTP} / \mathrm{ATP}_{\mathrm{i}, \mathrm{t}}+\beta_{4} \mathrm{PCT}_{\mathrm{i}, \mathrm{t}}+\beta_{5} \mathrm{LTA}_{\mathrm{i}, \mathrm{t}}+\beta_{6} \mathrm{FA} \mathrm{TA}_{\mathrm{i}, \mathrm{t}}+$ $\beta_{7} \mathrm{INV} / \mathrm{TA}_{\mathrm{i}, \mathrm{t}}+\beta_{8} \mathrm{OCF} / \mathrm{TA}_{\mathrm{i}, \mathrm{t}}+\mu_{\mathrm{i}, \mathrm{t}}$

\section{Descriptive Statistics}

\section{RESULTS AND FINDINGS}

Table 3 concluding the descriptive measurements for the ward and the different variables. This appears the normal markers of variables registered from the money related report. This generally low extent of the altered resources could be clarified by the very way of protection business. The necessity of specialized dissolvability stresses liquidity, security and accessibility of venture so that leasing companies can meet their liabilities when they do happen. Additionally, as an administration industry, they may not depends such a great amount on altered resources.

Table 4: Descriptive Analysis

\begin{tabular}{|c|c|c|c|c|c|c|c|c|c|c|}
\hline & $T D / T A$ & $T D / T E$ & $R O A$ & $S D . R$ & PTP/ATP & $P C T$ & LTA & FA/TA & $I N V / T A$ & $O C F / T A$ \\
\hline Mean & 0.781908 & 4.004231 & -0.01960 & 0.025939 & 0.690001 & -0.05862 & 14.36719 & 0.077538 & 0.343628 & 0.013807 \\
\hline Median & 0.792627 & 2.96076 & 0.007500 & 0.023467 & 1.109346 & -0.23072 & 14.25742 & 0.038857 & 0.357300 & 0.014452 \\
\hline Maximum & 2.819667 & 44.89457 & 0.375100 & 0.058925 & 2.137392 & 18.47215 & 17.14109 & 0.681492 & 0.972600 & 0.372681 \\
\hline Minimum & 0.111200 & -36.9327 & -0.70640 & 0.010036 & -34.73121 & -11.5392 & 11.48911 & 0.000311 & 0.000000 & -0.66976 \\
\hline Std. Dev. & 0.335242 & 8.319845 & 0.127429 & 0.011233 & 4.053548 & 3.517093 & 1.362093 & 0.129845 & 0.251507 & 0.152816 \\
\hline Skewness & 2.849041 & 0.180177 & -2.95325 & 0.843782 & -8.605059 & 1.420189 & 0.312796 & 3.387407 & 0.383051 & -0.79167 \\
\hline Kurtosis & 18.86668 & 16.39938 & 17.39322 & 3.072208 & 75.71047 & 14.64844 & 2.804006 & 14.62570 & 2.686674 & 7.047043 \\
\hline Observations & 90 & 90 & 90 & 90 & 90 & 79 & 90 & 90 & 90 & 90 \\
\hline
\end{tabular}

\section{Empirical Findings}

The pooled regression depends on the presumption that the captures are the same for every one of the banks and for all the periods from 2006 to 2015. Return on value as intermediary for measuring gainfulness of the banks has been utilized as dependant variable. At the second stage business sector to book estimation of the banks is considered as the dependant variable. Accepting equal of influence (ECAP), profit hazard (SDROE), size of bank, Herfindahl File (HERF), leasing interest in securities as extent of aggregate resources of the bank (SEC) and shopper situated credits as extent of benefits (Loans) make our decision of variables and the outcomes are accounted for in the Table 1. Keeping in mind the end goal to control the issue of Heteroskedasticity over the banks furthermore over the day and age, the estimation of pooled information was done in two phases.

Table 5: Correlation Matrix

\begin{tabular}{|c|c|c|c|c|c|c|c|c|c|c|}
\hline & TD/TA & TD/TE & ROA & SD.R & PTP/ATP & PCT & LTA & FA/TA & INV/TA & OCF/TA \\
\hline TD/TA & 1.000000 & & & & & & & & & \\
\hline TD/TE & 0.027452 & 1.000000 & & & & & & & & \\
\hline ROA & -0.58943 & -0.062203 & 1.000000 & & & & & & & \\
\hline SD.R & -0.191328 & -0.211616 & 0.068162 & 1.000000 & & & & & & \\
\hline PTP/ATP & -0.044262 & -0.046505 & -0.011157 & 0.074948 & 1.000000 & & & & & \\
\hline PCT & 0.018834 & -0.122363 & 0.111578 & 0.049063 & 0.033328 & 1.000000 & & & & \\
\hline LTA & 0.182334 & 0.323394 & 0.091942 & -0.108811 & -0.059285 & -0.060265 & 1.000000 & & & \\
\hline FA/TA & -0.146874 & -0.104560 & 0.061125 & -0.003638 & 0.072834 & 0.046544 & -0.478780 & 1.000000 & & \\
\hline INV/TA & -0.189916 & 0.003417 & 0.095613 & 0.246228 & -0.071308 & -0.104648 & -0.001901 & -0.405775 & 1.000000 & \\
\hline OCF/TA & \begin{tabular}{|l|}
0.002109 \\
\end{tabular} & -0.019229 & -0.000130 & 0.033450 & -0.084103 & -0.136620 & 0.109733 & -0.033818 & -0.214410 & 1.000000 \\
\hline
\end{tabular}

Pearson Correlation was utilized to check the connection among the variables. Table 4 demonstrates that how variables are connected with each other. Relationship between's DPS what's more, DY is exceptionally positive, while that between influence DR and DPS is negative, demonstrating that there is an reverse relationship amongst obligation and profit, i.e. increment in the red is not valuable for profit). It too demonstrates that exceptionally utilized firms are paying less profits. Then again, the expansion in DY will expand DPS which is a 
recognizable proof of the reshaping.

What would it be advisable for us to do to lessen multicollinearity in the relapse model? We need to consider the accompanying strides:

- For lessening multicollinearity we can incorporate more variables in the model. Because of which change of unsettling influences diminishes.

- We can decrease it by expanding the quantity of perceptions.

- Combined those variables which have high collinearity.

- Drop some related autonomous variables.

Table 6: Results of Debt to Assets Proxy with the help of Fixed Effect Panel Least Square Model Dependent Variable: TD/TA

Total panel (unbalanced) observations: 79

\begin{tabular}{|c|c|c|c|c|}
\hline Variable & Coefficient & Std. Error & t-Statistic & Prob. \\
\hline $\mathrm{C}$ & 2.359859 & 0.728948 & 3.237352 & 0.0020 \\
\hline ROA & -0.696980 & 0.265777 & -2.622423 & 0.0111 \\
\hline SD.R & -5.843359 & 3.200392 & -1.825826 & 0.0729 \\
\hline PTP/ATP & $6.24 \mathrm{E}-05$ & 0.006503 & 0.009598 & 0.9924 \\
\hline PCT & 0.004222 & 0.007289 & 0.579243 & 0.5646 \\
\hline LTA & -0.114382 & 0.048791 & -2.344320 & 0.0224 \\
\hline $\mathrm{FA} / \mathrm{TA}$ & 2.302652 & 0.924674 & 2.490230 & 0.0156 \\
\hline INV/TA & 0.074461 & 0.136587 & 0.545155 & 0.5877 \\
\hline \multirow[t]{2}{*}{$\mathrm{OCF} / \mathrm{TA}$} & -0.044982 & 0.201850 & -0.222848 & 0.8244 \\
\hline & \multicolumn{4}{|c|}{ Effects Specification } \\
\hline \multicolumn{5}{|c|}{ Cross-section fixed (dummy variables) } \\
\hline R-squared & 0.696034 & \multicolumn{2}{|c|}{ Mean dependent var } & 0.781908 \\
\hline Adjusted R-squared & 0.604844 & \multicolumn{2}{|c|}{ S.D. dependent var } & 0.335242 \\
\hline S.E. of regression & 0.210738 & \multicolumn{2}{|c|}{ Akaike info criterion } & -0.070494 \\
\hline Sum squared resid & 2.664626 & \multicolumn{2}{|c|}{ Schwarz criterion } & 0.499373 \\
\hline Log likelihood & 21.78452 & \multicolumn{2}{|c|}{ Hannan-Quinn criter. } & 0.157812 \\
\hline F-statistic & 7.632799 & \multicolumn{2}{|c|}{ Durbin-Watson stat } & 0.907554 \\
\hline Prob(F-statistic) & 0.000000 & & & \\
\hline
\end{tabular}

The after effects of the Prais-Winsten regression between influence (subordinate variable) and the autonomous variables are introduced in Table 4. The outcomes demonstrate a factually huge positive relationship between size and influence. This means, leasing companies with bigger size have low rate of likelihood of default and consequently their capacity to utilize more obligation assets. This backing the exchange off hypothesis recommending that bigger firm's display lower likelihood of default. Obligation capital suppliers are more agreeable in loaning to extensive protection firms than the little ones, this is on the grounds that the bigger ones can enhance their operations what's more, consequently diminish their danger profile. The leasing companies utilized less obligation in their capital structure on account of the issue of data asymmetries. 


\section{Table 7: Results of Debt to Equity Proxy with the help of Random Effect Generalized Least Square} Model

\section{Dependent Variable: TD/TE}

Method: Panel EGLS (Cross-section random effects)

White diagonal standard errors \& covariance (no d.f. correction)

\begin{tabular}{|c|c|c|c|c|}
\hline Variable & Coefficient & Std. Error & t-Statistic & Prob. \\
\hline $\mathrm{C}$ & -32.80036 & 12.17211 & -2.694714 & 0.0088 \\
\hline ROA & -10.08644 & 4.587404 & -2.198726 & 0.0312 \\
\hline SD.R & -145.5353 & 43.76935 & -3.325051 & 0.0014 \\
\hline PTP/ATP & 0.011111 & 0.055776 & 0.199212 & 0.8427 \\
\hline PCT & -0.134525 & 0.140447 & -0.957837 & 0.3414 \\
\hline LTA & 2.701030 & 0.903192 & 2.990538 & 0.0038 \\
\hline FA/TA & 8.979317 & 4.213645 & 2.131009 & 0.0366 \\
\hline INV/TA & 1.904237 & 2.225774 & 0.855539 & 0.3952 \\
\hline \multirow[t]{2}{*}{$\mathrm{OCF} / \mathrm{TA}$} & -3.133278 & 6.220956 & -0.503665 & 0.6161 \\
\hline & \multicolumn{2}{|c|}{ Effects Specification } & S.D. & Rho \\
\hline \multirow{3}{*}{$\begin{array}{l}\text { Cross-section random } \\
\text { Idiosyncratic random }\end{array}$} & & & 5.589404 & 0.3399 \\
\hline & & & 7.789765 & 0.6601 \\
\hline & \multicolumn{3}{|c|}{ Weighted Statistics } & \\
\hline R-squared & 0.127260 & Mean depe & & 1.727279 \\
\hline Adjusted R-squared & 0.027519 & S.D. depen & & 7.491175 \\
\hline S.E. of regression & 7.405404 & Sum squar & & 3838.800 \\
\hline F-statistic & 1.275900 & Durbin-W & & 2.170981 \\
\hline \multirow[t]{2}{*}{ Prob(F-statistic) } & 0.270164 & & & \\
\hline & \multicolumn{3}{|c|}{ Unweighted Statistics } & \\
\hline R-squared & 0.149894 & Mean depe & & 4.004231 \\
\hline Sum squared resid & 4589.847 & Durbin-W & & 1.815738 \\
\hline
\end{tabular}

The after effects of the OLS relapse between influence (subordinate variables) and the logical variables are accounted for in Table 6. The outcomes demonstrate a negative relationship amongst productivity and influence. The outcomes, which are additionally predictable with past studies (Titman and Wessels, 1988; Barton et al., 1989) demonstrate that, higher benefits expand the level of inner financing. Gainful banks aggregate internals stores and this empowers them to depend less on outside assets. Despite the fact that beneficial banks may have better access to outer financing, the requirement for obligation account may conceivably be lower, if new speculations can be financed from gathered stores.

This finding is steady with the pecking request hypothesis that proposes that beneficial firms favor inside financing to outside financing. There is no backing of danger impacting the level of influence of banks in Ghana. The coefficient for danger on influence is sure and factually immaterial. This discovering brings up an issue as whether danger is critical in the capital structure of banks in Pakistan

\section{Discussion}

\section{CONCLUSION}

In the analysis of breaking down information with help of Pearson's relationship and customary slightest square relapse it is concentrated on that there is a critical relationship exist between turnover proportions and liquidity proportions in leasing companies of Karachi 
Stock Exchange. In this study created five log-direct models and tried the hypothesis for partial regression coefficients. With the assistance of the relationship the study was considered between turnover proportions and liquidity proportions. Study found that the expansion in records receivable turnover and stock turnover will increment in net working capital however increment in records receivable turnover in days, stock turnover in days what's more, money transformation cycle will diminish in net working capital.

The positive effect of records receivable turnover was found on net working capital. The concentrate likewise found that the expansion in records receivable turnover, accounts turnover in days, stock turnover and stock turnover in days would build the current proportion. Basic analysis proportion can be expanded by expanding records of sales turnover, debt claims turnover in days, stock turnover and stock turnover in days however it can be diminished because of expansion in money transformation cycle. Money proportion was not influenced by turnover proportions in light of the fact that there was no critical relationship contemplated between money proportion and turnover proportions. At long last the deals to working capital proportion might be influenced by stock turnover in days and money transformation cycle. Increment in stock turnover in days would build the deals to working capital proportion however increment in real money transformation cycle would diminish deals to working capital proportion.

\section{Conclusion}

The after effects of this study give some helpful data about the capital structure of Pakistan leasing industry. Results got from the exact examination demonstrate that development benefit age of the firm and liquidity have huge impact on Pakistan leasing companies. In addition, it can likewise be expressed that the discoveries show prove that static exchange off hypothesis; pecking request hypothesis and organization hypothesis are halfway acknowledged in protection part of Pakistan however the exchange off hypothesis seems to rule the Pakistan protection division capital structure.

\section{Future Researches}

There is still parcel of work required in Pakistan to investigate more issues identified with respect to capital structure. Model particular and variables choice can be enhanced in future examines in light of the fact that in this work the high variety considered in budgetary information. The impact of Skewness and Kurtosis can be incorporated as a variable in the model to concentrate more steady results since information instability assume measure part in testing hypotheses.

At the point when returns fall outside of an ordinary circulation, the conveyance displays skewness or kurtosis. Skewness is known as the third "minute" of an arrival dispersion and kurtosis is known as the fourth snapshot of the arrival dissemination, with the mean and the fluctuation being the first and second minutes, individually. (Difference is a measurement that is firmly identified with standard deviation; both measure the scattering of a speculation's chronicled returns.) Ideally, speculators ought to consider every one of the four minutes or qualities of a venture's arrival conveyance.

\section{References}

Aziz, A., Khoso, I., Jamali, N. M. (2015). IMPACT OF SPECIFIC FACTORS ON CAPITAL STRUCTURE DECISIONS: A CASE OF PAKISTAN MOTOR VEHICLES, TRAILER AND AUTO PARTS INDUSTRY, Grassroots, 49(2)

Abor (2005). The effect of capital structure on profitability: an empirical analysis of listed firms in Ghana. The Journal of Risk Finance, 6(5), 438-445 
Ali (2011). Determinants of Capital Structure: Empirical Evidence from Pakistan, University of Twente Enschede. The Netherlands, 1-69

Al-Najjar (2011). Revisiting the capital-structure puzzle: UK evidence. The Journal of Risk Finance, 12( 4), 329338

Amidu (2007). Determinants of capital structure of banks in Ghana: an empirical approach. Baltic Journal of Management 2(1), 67-79

Amjed, Sohail, Impact of Financial Structure on Firm's Performance: A Study of Pakistan's Chemical Sector (June 20, 2011). Society of Interdisciplinary Business Research (SIBR) 2011 Conference on Interdisciplinary Business Research. Available at SSRN: https://ssrn.com/abstract=1867882 or http://dx.doi.org/10.2139/ssrn.1867882

Antoniou, Paudyal and Guney (2008). The Determinants of Capital Structure: Capital Market-Oriented Versus Bank-Oriented Institutions. Journal of Financial and Quantitative Analysis, retrieved from: https://www.researchgate.net/publication/227406434

Atiq, Rafiq, Iqbal (2008). The Determinants of Capital Structure of the Chemical Industry in Pakistan. The Lahore Journal of Economics 13(1), 139-158

Bokpin and C. Arko (2009).Ownership structure, corporate governance and capital structure decisions of firms Empirical evidence from Ghana. Studies in Economics and Finance, 26(4), 246-256

Basil Al-Najjar and Peter Taylor (2008). The relationship between capital structure and ownership structure, Managerial Finance Emerald Group Publishing Limited, 34(12), 919-931

Bharathi (2010). The Intellectual Capital Performance of Banking Sector in Pakistan. Pak. J. Commer. Soc. Sci., 4(1), 84-99

Bokpin (2009). Macroeconomic development and capital structure decisions of firms Evidence from emerging market economies. Studies in Economics and Finance, 26(2), 129-142

C. MYERS and S. MAJLUF (1984). Corporate Financing And Investment Decisions When Firms Have Information That Investors Do Not Have. Journal of Financial Economics, 13, 187-221

Capital Structure Theory - Modigliani and Miller (MM) Approach, Retrieved august 24,2016, https://www.efinancemanagement.com/financial-leverage/capital-structure-theory-modigliani-and-miller-mmapproach

Carpentier (2006). The valuation effects of long-term changes in capital structure, International Journal of Managerial Finance, 2(1), 4-18

Christian Svensson, Eduard Ciorogariu (2009). Determinants of Capital Structure and the Cost of Capital A Time and Industry differentiated Study on Swedish Listed Firms, Lund University School of Economics and Mangement8(9), 1-77

Ebaid (2009). The impact of capital structure choice on firm performance: empirical evidence from Egypt. The Journal of Risk Finance, 10(5), 477-487

Eriotis (2007). How firm characteristics affect capital structure: an empirical study, Managerial Finance, 33(5), 321-331

Ezeoha (2008) Firm size and corporate financial leverage choice in a developing economy: Evidence from Nigeria. THE JOURNAL OF RISK FINANCE, 9( 4), 351-364

F. FAMA and R. FRENCH (1998). Taxes, Financing Decisions, and Firm Value. The Journal of Finance, LIII(3), 819843

G. Rajan and Zingales (1995). What Do We Know about Capital Structure? Some Evidence from International Data. The Journal of Finance, 50(5), 1421-146

Gohar, Rehman, Shahid and Baig (2015). Effect of Capital Structure on Firms' Financial Performance: Empirical Evidence in Case of Construction and Materials (Cement) Sector of KSE-100 Index. Research Journal of Finance and Accounting, 6(15), 29-35

Graham and Leary (2005). A Review of Empirical Capital Structure Research and Directions for the Future. NATIONAL BUREAU OF ECONOMIC RESEARCH, 1-59

Gropp and Heider (2008). The Determinants of Capital Structure: Some Evidence from Banks, Centre for European Economic Research (ZEW) Mannheim, 1-39

Harris and Raviv (1991). The Theory of Capital Structure. The Journal of Finance, 46(1), 297-355 
Knatterud.,G.L., Rockhold, F.W., George, S.L., Barton, F.B., Davis, C.E., Fairweather, W.R., Honohan, T., Mowery, R, O’Neill, R. (1998). Guidelines for quality assurance in multicenter trials: a position paper. Controlled Clinical Trials, 19:477-493.

Kosmidou (2008). The determinants of banks'profits in Greece during the period of EU financial integration, Managerial Finance, 34(3), 146-159

Kyereboah-Coleman (2007).The impact of capital structure on the performance of microfinance Institutions. The Journal of Risk Finance, 8(1), 56-71

Margaritis and Psillaki (2007). Capital Structure and Firm Efficiency, Journal Of Business Finance \& Accounting, $34(9)$ \& (10), 1447-1469

MARSH (1982). The Choice Between Equity and Debt: An Empirical Study. THE JOURNAL OF FINANCE, XXXVII(1), 121-144

\section{MERTONH, MILLER (1977). DEBT AND TAXES. The Journal of Finance, XXXII (2), 262-275}

Michael Devereux and Fabio Schiantarelli (1990). Investment, Financial Factors, and Cash Row: Evidence from U.K. Panel Data, University of Chicago Press 0-226-35585-3, 279 - 306

Mubin, M., Iqbal, A. A., \& Hussain, A. (2014). Determinant of Return on Assets and Return on Equity and Its Industry Wise Effects: Evidence from KSE (Karachi Stock Exchange). Research Journal of Finance and Accounting, 5(15), 148-157.

Mubin, M., Ahmed, M., Farrukh, M., Lal, I., \& Hussain, A. (2014). Determinants of dividend with industry - wise effect-Evidence from KSE 100 Index. Journal of Finance and Accounting, 5(3), 62-69.

Modigliani, F. \& Miller, M. H (1958). The Cost of Capital, Corporation Finance and the Theory of Investment. The American Economic Review, 48(3), 261-297

Most, .M.M., Craddick, S., Crawford, S., Redican, S., Rhodes, D., Rukenbrod, F., Laws, R. (2003). Dietary quality assurance processes of the DASH-Sodium controlled diet study. Journal of the American Dietetic Association, 103(10): 1339-1346.

Naveed, Zulfqar and Ahmed (2010). Determinants of Capital Structure: A Case of Life Insurance Sector of Pakistan. European Journal of Economics. Finance and Administrative Sciences, 24, 8-12

Ooi (1999). The determinants of capital structureEvidence on UK property companies. Journal of Property Investment \& Finance, 17(5), 464-480.

Rahman and Kakakhel (2012). Determinants of Capital Structure Decision of Pakistani Insurance Industry. Abasyn Journal of Social Science, 9(1), 221-232

Rahman, Kakakhel and Iqbal (2013). Capital Structure Decision of Insurance Industry of Pakistan. Abasyn Journal of Social Sciences, 7(2), 328-335

Rehman (2013). "Relationship between Financial Leverage and Financial Performance: Empirical Evidence of Listed Sugar Companies of Pakistan”. Global Journal of Management and Business Research Finance, 13(8), 33-40

Saeed, Gull and Rasheed (2013). Impact of Capital Structure on Banking Performance (A Case Study of Pakistan). Interdisciplinary Journal Of Contemporary Research In Business, 4(10), 393-403

Shah and Kausar (2012). Determinants of capital structure of leasing companies in Pakistan. Applied Financial Economics, 22, 1841-1853

Shaheen and Malik (2012). The Impact of Capital Intensity, Size of Firm And Profitability on Debt Financing In Textile Industry of Pakistan. INTERDISCIPLINARY JOURNAL OF CONTEMPORARY RESEARCH IN BUSINESS, 3(10), 1061-1066

Shahid Hameed (2000). The future of Leasing Sector in Pakistan, Retrieved august 24, 2016, http://www.pakistaneconomist.com/issue2000/issue45/etc4.htm

Sheikh and Wang (2013). The impact of capital structure on performance An empirical study of non-financial listed firms in Pakistan. International Journal of Commerce and Management, 23(4), 354-368

Sheikh and Wang (2011). Determinants of capital structure An empirical study of firms in manufacturing industry of Pakistan. Managerial Finance, 37(2), 117-133

Shoney and Koch (1999). The firm's leverage-cash flow relationship. Journal of Empirical Finance, 2, $302-331$ 
Siddiqui1 and Shoaib (2011). Measuring performance through capital structure: Evidence from banking sector of Pakistan, African Journal of Business Management, 5(5), 1871-1879

TITMAN and WESSELS (1998). The Determinants of Capital Structure Choice. THE JOURNAL OF FINANCE, XLIII (1), 1-19

Tornyeva (2013). Determinants of Capital Structure of Insurance Companies in Ghana. Research Journal of Finance and Accounting,4(13), 52-60

Vohra, Mohsin and Raza, Hasan and Aslam, Muhammad Farrukh and Mubin, Muhammad, Impact of Working Capital Management on Financial Charges: Empirical Evidence of Manufacturing Industry of Pakistan (August 20, 2014). Research Journal of Finance and Accounting, Vol. 9, Issue 20, pp 110-119 (2014). Available at SSRN: https://ssrn.com/abstract=2910480

W. Diamond and G. Rajan (1999). A Theory of Bank Capital, NATIONAL BUREAU OF ECONOMIC RESEARCH Working Paper No. 7431, 1-50

Whitney, C.W., Lind, B.K., Wahl, P.W. (1998). Quality assurance and quality control in longitudinal studies. Epidemiologic Reviews, 20(1): 71-80. 